\title{
The Blake geomagnetic excursion recorded in a radiometrically dated speleothem
}

\author{
María-Luisa Osete ${ }^{\mathrm{a}, \mathrm{b}, *}$, Javier Martín-Chivelet ${ }^{\mathrm{b}, \mathrm{c}}$, Carlos Rossi $^{\mathrm{d}}$, R. Lawrence Edwards ${ }^{\mathrm{e}}$, Ramon Egli ${ }^{\text {, }}$ \\ M. Belén Muñoz-García ${ }^{\text {c }}$, Xianfeng Wang ${ }^{\text {, }}$, F. Javier Pavón-Carrasco ${ }^{a}$, Friedrich Heller ${ }^{\mathrm{h}}$ \\ ${ }^{a}$ Dept. Fisica de \\ b Instituto de Geociencias (IGEO) CSIC-UCM, Ciudad Universitaria, 28040 Madrid, Spain \\ la Tierra I, Facultad de Ciencias Fisicas, \\ 'Dept. Estratigrafia, Facultad de Ciencias Geológicas, Universidad Complutense, 28040 Madrid, Spain \\ - Dept. Petrología y Geoquímica, Facultad de Ciencias Geológicas, Universidad Complutense, 28040 Madrid, Spain \\ e Department of Geology and Geophysics, University of Minnesota, MN 55455, USA \\ 'Department für Geo-und Umweitwissenschaften, Ludwig-Maximiians Universität, 80333 München, Germany \\ ${ }^{8}$ Earth Observatory of Singapore, Nanyang Technological University, Singapore 639798, Singapore \\ ${ }^{\mathrm{h}}$ Institut für Geophysik, ETH-Zentrum, CH-8092 Zürich, Switzeriand
}

Keywords:

geomagnetic excursions

speleothems

radioisotope geochronology

palaeointensity

rock magnetism

quaternary geochronology

\begin{abstract}
A B S T R A C T
One of the most important developments in geomagnetism has been the recognition of polarity excursions of the Earth's magnetic field. Accurate timing of the excursions is a key point for understanding the geodynamo process and for magnetostratigraphic correlation. One of the bestknown excursions is the Blake geomagnetic episode, which occurred during marine isotope stage MIS 5 , but its morphology and age remain controversial. Here we show, for the first time, the Blake excursion recorded in a stalagmite which was dated using the uranium-series disequilibrium techniques. The characteristic remanent magnetisation is carried by fine-grained magnetite. The event is documented by two reversed intervals (B1 and B2). The age of the event is estimated to be between $116.5+0.7 \mathrm{kyr}$ $\mathrm{BP}$ and $112.0+1.9 \mathrm{kyr} \mathrm{BP}$, slightly younger $(\sim 3-4 \mathrm{kyr})$ than recent estimations from sedimentary records dated by astronomical tuning. Low values of relative palaeointensity during the Blake episode are estimated, but a relative maximum in the palaeofield intensity coeval with the complete reversal during the B2 interval was observed. Duration of the Blake geomagnetic excursion is $4.5 \mathrm{kyr}$, two times lower than single excursions and slightly higher than the estimated diffusion time for the inner core $(\sim 3 \mathrm{kyr})$.
\end{abstract}

\section{Introduction}

Understanding the origin, duration and the field behaviour associated with excursions is a forefront research area within solid earth geophysics (Roberts, 2008). Precise evaluation of the duration of geomagnetic excursions has become a point of interest since Gubbins (1999) proposed that excursions occurred when the field in the Earth's liquid core reverses polarity without accompanying field reversal in the solid inner core.

\footnotetext{
* Corresponding author at: Dept. Fisica de la Tierra I, Facultad de Ciencias Físicas, Universidad Complutense, 28040 Madrid, Spain. Tel.:+34913944396; fax: +34913944398

E-mail addresses: mlosete@fis.ucm.es (M. -L. Osete), j.m.chivelet@geo.ucm.es (J. Marín-Chivelet), crossi@geo.ucm.es (C. Rossi), edwar001@umn.edu (R. Lawrenc. Edwards), egli@geophysik.uni-muenchen.de (R. Egli), mbmunoz@geo.ucm.es (M. Belé. Muñoz-García), xianfeng.wang@ntu.edu.sg (X. Wang), fjpavon@fis.ucm.es (F. Javie. Pavón-Carrasco), heller@mag.ig.erdw.ethz.ch (F. Heller)
}

This mechanism and the corresponding estimation of diffusion times for the inner core provide a prediction for excursion duration: around $3 \mathrm{kyr}$. This model has become a standard explanation for excursions. However, precise duration of some excursions is still unknown.

The Blake geomagnetic excursion was first identified by Smith and Forster (1969). Since then it has been reported in different records, including oceanic sediments (Tric et al., 1991; Thouveny et al., 2004; Lund et al., 2006) lacustrine sediments (Creer et al., 1980), loess deposits (Zhu et al., 1994; Reinders and Hambach, 1995; Fang et al., 1997) and continental sediments (Shier et al., 2011). But the morphology and age of the event still remain controversial. It seems to be characterised by two reversed polarity zones (Denham, 1976) or even by a single polarity zone (Tucholka et al., 1987). Age and duration estimates vary significantly in the literature. Extreme discrepancies for the onset of the Blake event have been given with $138 \mathrm{kyr}$ BP and $100 \mathrm{kyr}$ (Bleil and Gard (1989), and Denham (1976), respectively). Duration estimates range between 20 and $35 \mathrm{kyr}$ (Denham, 1976) with a 
minimum value of around $5 \mathrm{kyr}$ introduced by Tucholka et al. (1987). Studies on marine sediments suggest that this excursion occurred during marine isotope stage MIS 5, probably during substages 5e/5d (Thouveny et al., 2004; Channell, 2006). The general consensus is that the Blake event took place between 125 and $110 \mathrm{kyr}$ (Lund et al., 2006; Thouveny et al., 2004; Langereis et al., 1997), but absolute dating of the event is still lacking.

Calcite speleothems, such as stalagmites and flowstones, have an enormous potential in palaeomagnetism, since they may grow continuously through thousands of years, thereby preserving the palaeomagnetic signal at the time of calcite precipitation (Latham et al., 1979a, 1979b, 1987; Openshaw et al., 1993). The lock-in of the magnetisation is nearly instantaneous, and post-depositional effects are usually not very significant (Lascu and Feinberg, 2011). In addition, ages of speleothems can be determined with the high precision U-series radiometric dating techniques (e.g., Dorale et al., 2004).

Despite the great potential of speleothems for palaeomagnetic studies, the typically very low concentration of ferromagnetic minerals resulting in low Natural Remanent Magnetisation (Perkins and Maher, 1993; Perkins, 1996) has limited their usage. To our knowledge, no excursions have been unambiguously reported from a speleothem. In this paper, we provide for the first time radiometric and palaeomagnetic evidence for the age and characteristics of the Blake event that has been recorded in a speleothem in northern Spain.

\section{Studied material: C8 Stalagmite}

Stalagmite C8 was collected from Cobre Cave in northern Spain $\left(42^{\bullet} 59^{\prime} \mathrm{N}, 4^{\bullet} 22^{\prime} \mathrm{W}\right.$, elevation $\left.\sim 1600 \mathrm{~m}\right)$. This cave is located in the Sierra de Peñalabra, on the southern watershed of the Cantabrian Mountains (Fig. 1A). The cave has been developed in Carboniferous limestones and consists of an active low-gradient stream passage at the water table, and several relict low-gradient canyons at higher elevations (Rossi et al., 1997). The studied stalagmite was retrieved from a relict canyon, $\sim 1200 \mathrm{~m}$ distant from the cave entrance, $63 \mathrm{~m}$ above the resurgence elevation, and $\sim 100 \mathrm{~m}$ below the ground surface. The $\mathrm{C} 8$ sampling site is quite isolated from anthropogenic disturbance and external short-term environmental changes, with an air temperature of $5.5 \pm 0.3^{\circ} \mathrm{C}$ and a relative humidity of $98 \% \pm 2 \%$.

The recovered portion of $\mathrm{C} 8$ is $68 \mathrm{~cm}$ long, $15 \mathrm{~cm}$ wide at the base, and shows a roughly conical shape (Fig. 1B). Axial crosssections of $\mathrm{C} 8$ reveal an internal structure formed by light-brown to white, millimetric to centimetric-scale alternating bands, with no obvious indications of significant growth hiatuses (Fig. 1C and D). Both types of layers further contain internal growth laminae of micrometric scale (10-100 $\mu \mathrm{m}$ thick), more apparent in the flanks of the sample, and defined by variations in the abundance of aqueous fluid inclusions.

Previous work on stalagmite C8 includes petrographic and stable isotope analyses (Muñoz-García, 2007; Muñoz-García et al., 2007). As a whole, $\mathrm{C} 8$ shows no obvious signs of alteration or recrystallisation. Transmitted-light petrographic study using $\sim 500 \mu \mathrm{m}$-thick polished sections revealed that $\mathrm{C} 8$ is formed by highly transparent and relatively large calcite crystals $(m m-c m)$, elongated in the direction of growth and with length/width ratios usually between 6 and 10 (columnar fabric according to Frisia et al. (2000)). This is a typical primary fabric that precipitates by slow degassing of $\mathrm{CO}_{2}$ at or very close to conditions of isotopic equilibrium (Frisia et al., 2000). The stable isotope record of $\mathrm{C} 8$ includes a series of $\delta^{18} \mathrm{O}$ analyses performed along the growth axis (Fig. $2 \mathrm{~b}$ ). $\delta^{18} \mathrm{O}$ values range between $-7.08 \%$ and $-8.69 \%$ (VPDB), and vertical changes in these values outline four successive stratigraphic intervals, each of them defined by a consistent trend. These $\delta^{18} \mathrm{O}$ changes mainly reflect variations in the isotopic composition of seepage water, which are in turn largely controlled by the average composition of local meteoric waters (Muñoz-García, 2007). Cold intervals (as cold stadials) are positively correlated with lower values in the $\delta^{18} \mathrm{O}$, whereas warmer ones (as interstadials) show higher values. The isotopic record of $\mathrm{C} 8$ will be herein used as a reference to compare our palaeomagnetic results with previous sedimentary records of the Blake excursion the ages of which were constrained by astronomical tuning of the marine isotope stages.

\section{Methods}

Prior to its removal from the cave, C8 was oriented in situ using a magnetic compass and an inclinometer. 31 cubic
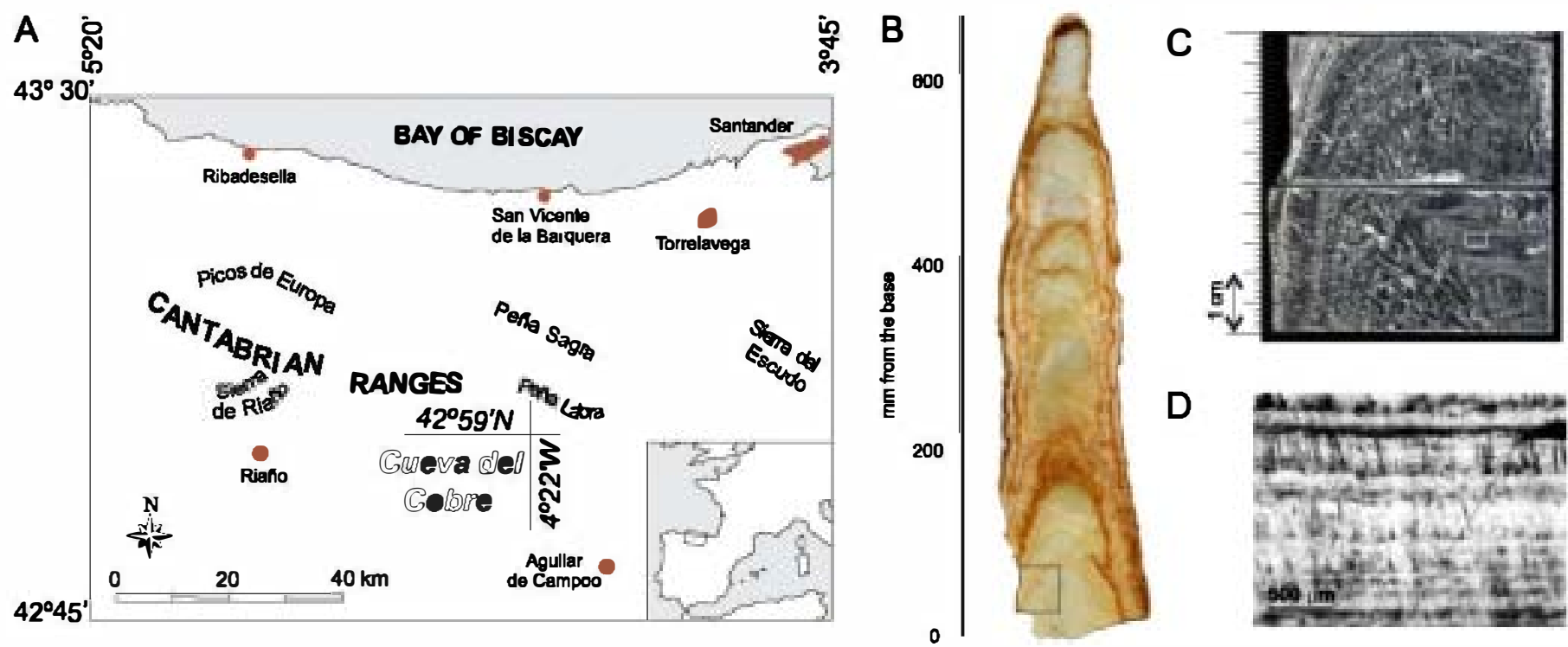

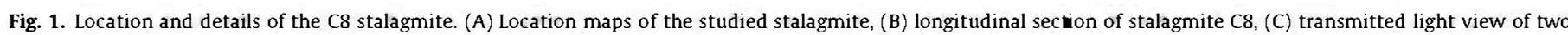

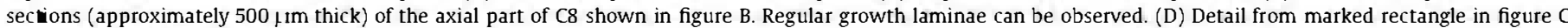
under petrographic microscopy. 

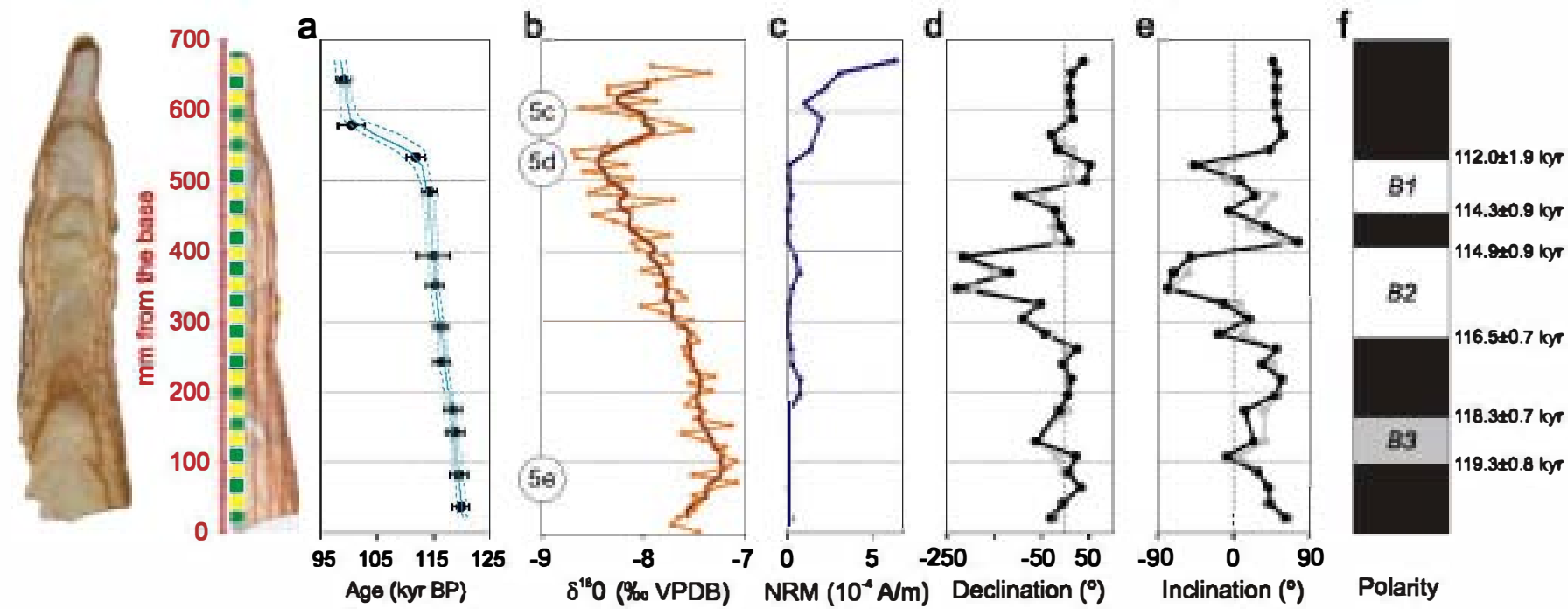

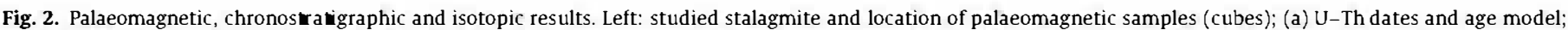

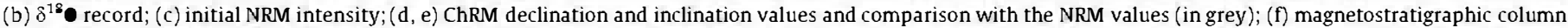
with normal (black), reversed (white) and ambiguous (grey) zones.

samples $\left(8 \mathrm{~cm}^{3}\right)$ were cut from the central part of an axial section of the stalagmite and used for palaeomagnetic analysis (Fig. 2, left). Palaeomagnetic studies were carried out at the Institut für Geophysik, ETH Zürich, Switzerland. The natural remanent magnetisation (NRM) of the samples was measured using a three-axis 2G-Enterprise cryogenic magnetometer. Samples were subjected to both thermal (TH) and alternating field (AF) demagnetisation cleaning. Stepwise TH demagnetisation of NRM was carried out in $20-50^{\circ} \mathrm{C}$ steps up to $580-$ $700^{\circ} \mathrm{C}$. Six samples exploded during heating at $300-650^{\circ} \mathrm{C}$, most likely due to the decrepitating of the abundant aqueous fluid inclusions. Stepwise AF demagnetisation was conducted in 2-20 $\mathrm{mT}$ steps up to $140 \mathrm{mT} .17$ samples were subjected to AF demagnetisation. After demagnetisation of these samples, an anhysteretic remanent magnetisation (ARM) was imparted at $200 \mathrm{mT}$ followed by very detailed AF demagnetisation and finally acquisition of isothermal remanent magnetisation (IRM) at $200 \mathrm{mT}$. These experiments were conducted to study the magnetic properties variations (Supplementary Table S1) and to perform relative palaeointensity (RPI) analyses (Tauxe, 1993). Stepwise acquisition of isothermal remanent magnetisation (IRM) up to $1800 \mathrm{mT}$ followed by isothermal remagnetisation in three orthogonal directions and subsequent progressive thermal demagnetisation were carried out on selected samples in order to identify the magnetic mineralogy of the samples (Lowrie, 1990). The field applied along the three orthogonal axes was $1800 \mathrm{mT}, 400 \mathrm{mT}$ and $250 \mathrm{mT}$.

Thirteen $\sim 200 \mathrm{mg}$ sub-samples were retrieved from $\mathrm{C8}$ along selected growth layers and prepared for ${ }^{230} \mathrm{Th}$ dating following procedures similar to those described by Edwards et al. (1987) and Dorale et al. (2004). Analyses were conducted in the Minnesota Isotope Laboratory of the University of Minnesota by means of an inductively coupled plasma mass spectrometer (ThermoFinnigan ELEMENT) using procedures described in Shen et al. (2002) and Dorale et al. (2004).

\section{Age model}

The age model for stalgmite $\mathrm{C} 8$ was based on thirteen ${ }^{230} \mathrm{Th}$ dates (summarised in Table 1). After the correction for initial ${ }^{230} \mathrm{Th} /{ }^{232} \mathrm{Th}$, the StalAge algorithm was applied (Scholz and
Hoffmann, 2011). According to obtained age model (Fig. 2a and Supplementary Table S1), C8 grew between $120.2 \pm 0.7 \mathrm{kyr}$ BP and $98.5 \pm 1.0 \mathrm{kyr} \mathrm{BP}$, covering the end of marine isotope stage (MIS) 5e, the whole of MIS 5d, and the onset of MIS 5c. Three main successive intervals of stalagmite growth can be recognised. The first one, which comprises the lowest $48 \mathrm{~cm}$ of the sample, grew between $\sim 120.2$ and $\sim 114.0 \mathrm{kyr} \mathrm{BP}$, and is characterised by an average growth rate of $\sim 72 \mu \mathrm{m} / \mathrm{yr}$. The second interval is $\sim 11 \mathrm{~cm}$ long and was deposited during the $\sim 114.0-100.3 \mathrm{kyr}$ BP time span, with an average growth rate of about $1 / 10$ of that of the previous interval. The third interval, recorded in the upper $\sim 8 \mathrm{~cm}$ of the stalagmite, covers the time interval between $\sim 100.3$ and $\sim 98.5 \mathrm{kyr}$ BP and shows a moderately recovered growth rate ( $\sim 46 \mu \mathrm{m} /$ year $)$.

\section{Palaeomagnetic results}

\subsection{Rock magnetic results}

IRM acquisition curves indicate major contributions from low coercivity minerals (Fig. 3a), but variable amounts of high coercivity minerals can be also observed, especially in lightbrown samples. Only ferrimagnetic minerals are detected in white samples. The low coercivity IRM is thermally demagnetized at $550^{\circ} \mathrm{C}$ (Fig. 3b) indicating the presence of magnetite. Maximum unblocking temperatures over $550^{\circ} \mathrm{C}$ of the high coercivity component suggest the additional presence of haematite in lightbrown samples.

Detailed analysis of ARM and IRM demagnetisation curves has been performed in selected samples (Fig. 3c). These analyses also indicate the presence of two magnetic phases in light-brown samples (Fig. 3d and e) and one magnetic component in white samples. A low coercivity component with a median destructive field (MDF) of $24.1 \mathrm{mT}$ of saturation ARM (SARM) and $20.5 \mathrm{mT}$ of saturation IRM (SIRM) predominates in all samples. The high coercivity component exhibits MDF values $>200 \mathrm{mT}$ (light-brown samples). Detailed thermal demagnetisation of IRM acquired at $300 \mathrm{mT}$ shows a wide distribution of unblocking temperatures up to a maximum of $575^{\circ} \mathrm{C}$. Similar magnetic properties for the low coercivity phase have also been found in British speleothems (Perkins and Maher, 1993). The magnetic 
Table 1

${ }^{230^{*}}$ Th dating results for stalagmite C8 by ICP-MS analysis.

\begin{tabular}{|c|c|c|c|c|c|c|c|c|}
\hline Sample ID & $\begin{array}{l}\text { Distance }^{\mathbf{a}} \\
(\mathrm{mm})\end{array}$ & $\begin{array}{l}{ }^{238} U^{b} \\
(p p b)\end{array}$ & $\begin{array}{l}{ }^{232} \mathrm{Th}^{\mathrm{b}} \\
\text { (ppt) }\end{array}$ & $\begin{array}{l}\delta^{234} U \\
\text { measured }^{c}\end{array}$ & $\begin{array}{l}\left.\mathrm{I}^{230} \mathrm{Th} /{ }^{238} \mathrm{U}\right] \\
\text { activity }\end{array}$ & $\begin{array}{l}\text { Age } \\
\text { (kyr, uncorrected) }\end{array}$ & $\begin{array}{l}\text { Age } e^{e, f} \\
\text { (kyr, corrected) }\end{array}$ & $\begin{array}{l}\delta^{234} U_{\text {initial }} \\
\text { corrected }^{5}\end{array}$ \\
\hline C8-1 & 643 & $149.6 \pm 0.5$ & $1385 \pm 6$ & $142 \pm 4$ & $0.698 \pm 0.004$ & $100.2 \pm 1.1$ & $99.2 \pm 1.2$ & $187 \pm 5$ \\
\hline C8-3 & 579 & $92.3 \pm 0.3$ & $2949 \pm 11$ & $72 \pm 4$ & $0.667 \pm 0.005$ & $104.5 \pm 1.4$ & $100.6 \pm 2.4$ & $96 \pm 5$ \\
\hline C8-15 & 534 & $41.1 \pm 0.2$ & $46 \pm 3$ & $97 \pm 4$ & $0.714 \pm 0.005$ & $112.1 \pm 1.6$ & $111.9 \pm 1.6$ & $133 \pm 6$ \\
\hline C8-16 & 485 & $166.4 \pm 0.6$ & $289 \pm 4$ & $163 \pm 3$ & $0.772 \pm 0.005$ & $114.6 \pm 1.3$ & $114.4 \pm 1.3$ & $225 \pm 5$ \\
\hline C8-18 & 393 & $173.6 \pm 0.6$ & $6682 \pm 29$ & $91 \pm 3$ & $0.737 \pm 0.005$ & $119.7 \pm 1.7$ & $115.0 \pm 2.9$ & $126 \pm 5$ \\
\hline$C 8-20$ & 352 & $151.5 \pm 0.7$ & $231 \pm 3$ & $107 \pm 4$ & $0.734 \pm 0.005$ & $115.5 \pm 1.5$ & $115.3 \pm 1.5$ & $150 \pm 6$ \\
\hline C8-22 & 293 & $184.6 \pm 0.6$ & $489 \pm 3$ & $96 \pm 3$ & $0.730 \pm 0.004$ & $116.6 \pm 1.4$ & $116.3 \pm 1.4$ & $134 \pm 5$ \\
\hline C8-24 & 243 & $123.3 \pm 0.5$ & $1187 \pm 5$ & $85 \pm 4$ & $0.725 \pm 0.005$ & $117.6 \pm 1.6$ & $116.5 \pm 1.6$ & $118 \pm 6$ \\
\hline$C 8-27$ & 175 & $158.1 \pm 0.6$ & $418 \pm 4$ & $93 \pm 4$ & $0.735 \pm 0.004$ & $118.7 \pm 1.5$ & $118.4 \pm 1.5$ & $130 \pm 5$ \\
\hline C8-28 & 143 & $160.2 \pm 0.6$ & $1030 \pm 6$ & $90 \pm 4$ & $0.736 \pm 0.005$ & $119.7 \pm 1.6$ & $118.9 \pm 1.7$ & $126 \pm 5$ \\
\hline C8-30 & 83 & $155.3 \pm 0.6$ & $284 \pm 4$ & $78 \pm 4$ & $0.727 \pm 0.005$ & $119.8 \pm 1.6$ & $119.6 \pm 1.6$ & $109 \pm 5$ \\
\hline C8-32 & 36 & $187.2 \pm 0.7$ & $120 \pm 4$ & $90 \pm 4$ & $0.737 \pm 0.004$ & $120.0 \pm 1.5$ & $119.9 \pm 1.5$ & $126 \pm 5$ \\
\hline
\end{tabular}

Analytical errors are $2 \sigma$ of the mean.

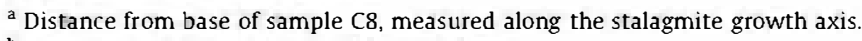

b $\mathrm{ppb}=$ parts per billion; $\mathrm{ppt}=$ parts per trillion.

c $\delta^{234} \mathrm{U}=\left(\left[{ }^{234} \mathrm{U} /{ }^{238} \mathrm{U}\right]_{\text {activity }}-1\right) \times 1000$.

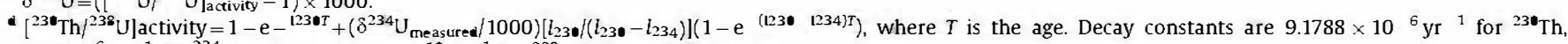
$2.8263 \times 10^{6} \mathrm{yr}{ }^{1}$ for ${ }^{234} \mathrm{U}$, and $1.55125 \times 10^{10} \mathrm{yr}{ }^{1}$ for ${ }^{238} \mathrm{U}$ (Cheng et al., 2000).

e The degree of detrital ${ }^{230} \mathrm{Th}$ contamination is indicated by the $\left[{ }^{230} \mathrm{Th} /{ }^{232} \mathrm{Th}\right]$ atomic ratio instead of the activity ratio.

f Age corrections were calculated using an initial ${ }^{230^{6}} \mathrm{Th} /{ }^{232} \mathrm{Th}$ atomic ratio of $2.0 \times 10^{5} \pm 1.0 \times 10^{5}$ to get all dates into stratigraphic order

8 $\delta^{234} \mathrm{U}_{\text {initial }}$ corrected was calculated based on ${ }^{230} \mathrm{Th}$ age $(T)$, i.e., $d^{234} \mathrm{U}_{\text {initial }}=d^{234} \mathrm{U}_{\text {measured }} X \mathrm{e}^{1234 T}$, and $T$ is corrected age.
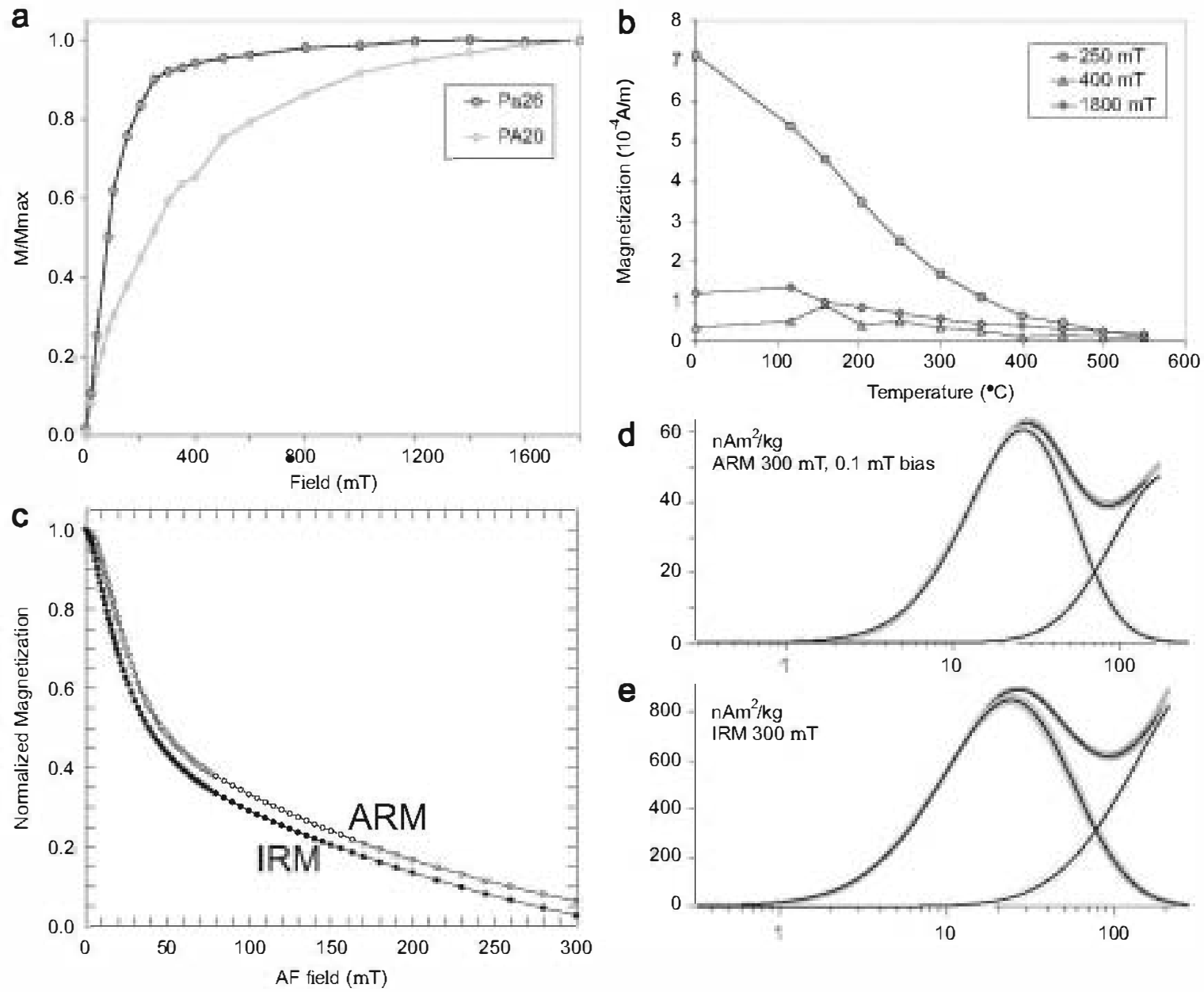

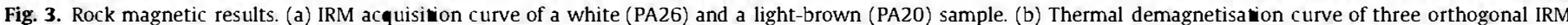

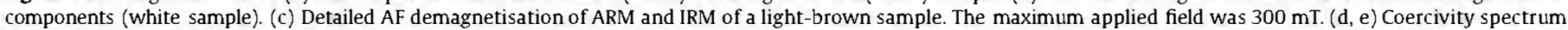
of the ARM (d) and IRM (e) components.

properties observed in speleothems seem to be in agreement with pedogenic or extracellular magnetite (Egli and Lowrie, 2003; Egli, 2004, Fig. 4). In summary, rock magnetic studies suggest the presence of fine-grained magnetite in the stalagmite samples as the main magnetic carrier of NRM and variable contribution of haematite in light-brown samples. 

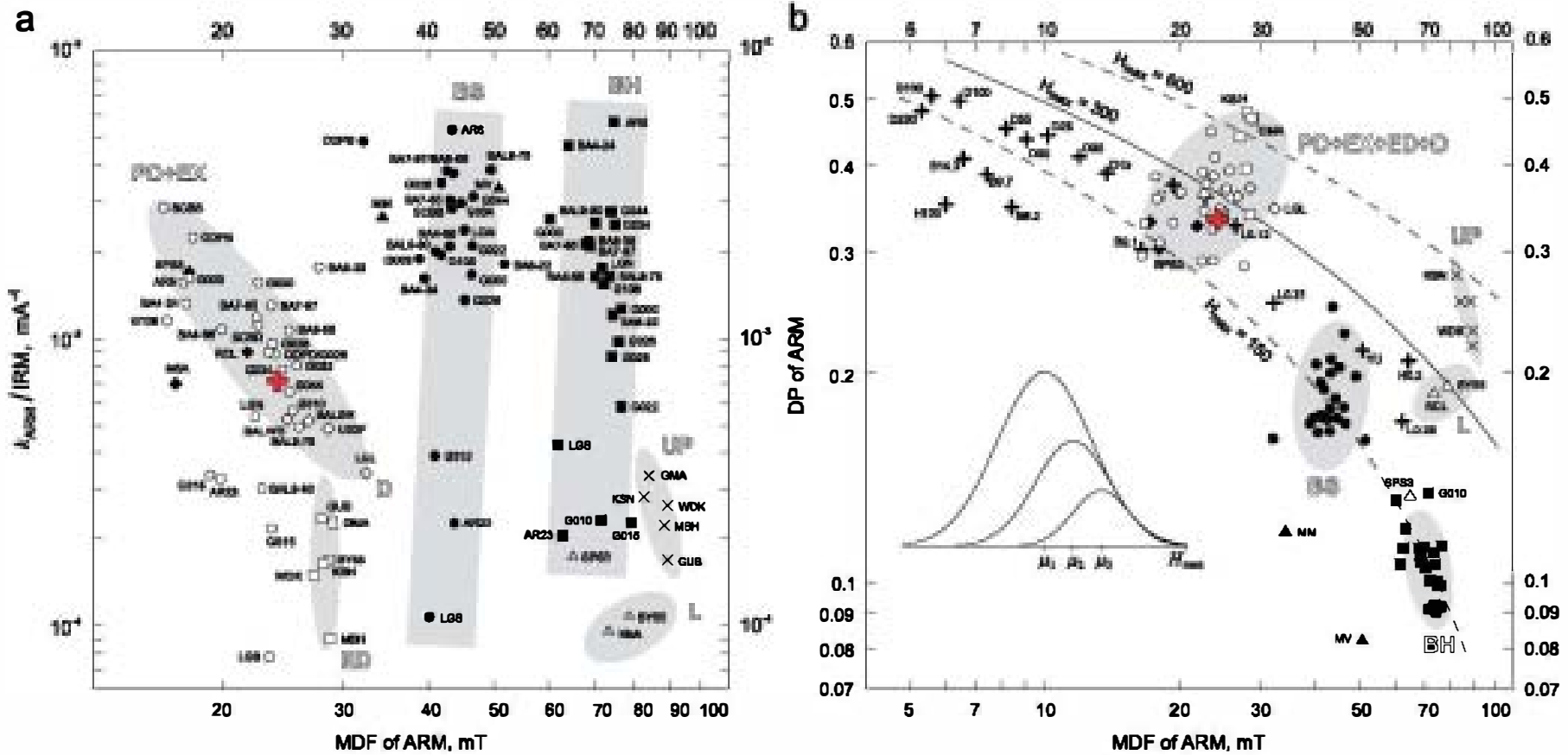

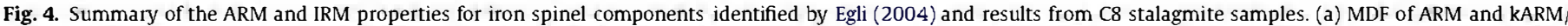

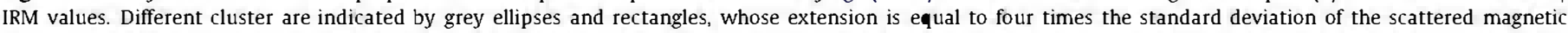

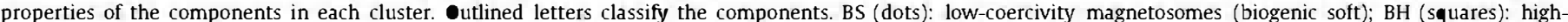

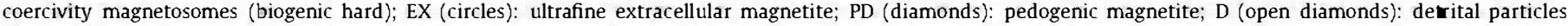

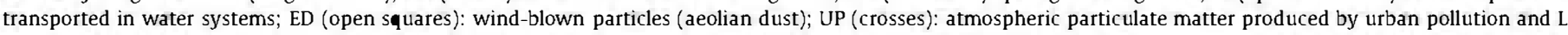

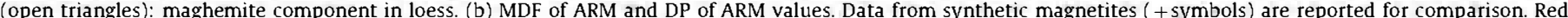

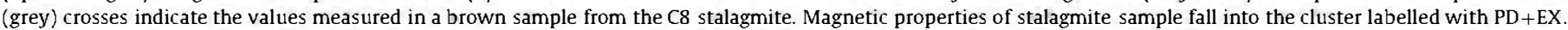
(For interpretation of the references to colour in this figure legend, the reader is referred to the web version of this article.)

\subsection{NRM results}

C8 is formed by nearly pure calcite, and as a consequence the magnetic intensity is very low. The initial NRM values ranged between 0.4 and $21.8 \times 10^{-5} \mathrm{~A} / \mathrm{m}$ (Fig. 2c and Supplementary Table S1). The highest NRM intensities were found in samples located in the upper $5 \mathrm{~cm}$ of the stalagmite. The lowest values were found in white calcite samples (from 4.0 up to $12 \times 10^{-6}$ $\mathrm{A} / \mathrm{m}$ ). Due to the low NRM intensities, the sample holder was demagnetised before each demagnetisation step and the magnetisation of the sample holder was measured before each measurement and subtracted from the magnetisation of the samples.

All samples exhibited upon demagnetisation a directionally stable low-coercivity/low-unblocking temperature component that is considered as the characteristic remanent magnetisation (ChRM) carried by fine magnetite. In spite of the low intensities of some samples the ChRM could be isolated both during AF (up to $50-80 \mathrm{mT}$ ) and thermal demagnetisation (up to $350-500^{\circ} \mathrm{C}$ ). The ChRM exhibited both, normal and reversed directions (Fig. 5).

Internal consistency has been observed between the magnetic polarity of the ChRM and sample position within the stalagmite (Fig. $2 \mathrm{~d}$ and e and Supplementary Table S1). All samples from the upper part of the stalagmite have normal polarity. An excursional event is suggested by four samples with largely fluctuating declinations and shallow, partly negative inclinations, located about $50 \mathrm{~cm}$ from the base of the stalagmite. Below this interval, two consecutive samples have normal polarities. Three reversed samples were identified in the central part of the stalagmite ( $\sim 35-40 \mathrm{~cm}$ from the base). In addition to these two clear reversed zones, three samples at $\sim 15 \mathrm{~cm}$ from the base of the stalagmite exhibit deviating westerly declinations of more than $45^{\circ} \mathrm{W}$ and very shallow, in one case negative, inclinations. The two directionally anomalous zones, from younger to older, have been labelled B1 and B2 and the less clear anomalous zone, found at the base of the stalagmite, has been named $\mathbf{B} 3$ (Fig. 2f). The excursional events have been defined when the virtual geomagnetic pole (VGP) exhibited a deviation of more than $40^{\circ}$ from the geographic pole. The frontiers of polarity intervals were calculated by linear interpolation.

In light-brown samples a higher coercivity-high unblocking temperature component carried by haematite could also be identified. This component always has normal polarity and is not present in samples consisting mostly of white calcite. The mean direction of the second component carried by haematite has a declination $D=2.6^{\circ \bullet}$ and an inclination $I=52.6^{\circ}(N=14, k=12$, $\alpha 95=11.9^{\circ}$ ), close to the present day field direction. It is considered as a secondary component.

\section{Discussion}

\subsection{Features and age of the Blake event in speleothem C8}

For the first time an excursion of the Earth's magnetic field has been recognised in a stalagmite and it has been accurately dated by means of the $U-T h$ disequilibrium technique. Our results support the existence of a geomagnetic polarity excursion characterised by a twofold reversal feature: $\mathbf{B} 1$ and $\mathbf{B} 2$ (Fig. $2 \mathrm{c}-\mathbf{f}$ ). The B2 event began at about $116.5 \pm 0.7 \mathrm{kyr}$ BP. It is well documented and reflects a full reversal of the geomagnetic field that ended at $114.9 \pm 0.9 \mathrm{kyr}$ BP. The B1 feature is not so well defined in C8 probably due to a decrease in stalagmite growth rate. The $\mathbf{B} 1$ event started at $114.3 \pm 0.9 \mathrm{kyr}$ BP (anomalous directions) and ended at $112.0 \pm 1.9 \mathrm{kyr}$ BP. We assign these reversals to the Blake geomagnetic polarity event and estimate its duration to be about $4.5 \mathrm{kyr}$ on the basis of our new U-Th age data. $\delta^{18} \mathrm{O}$ 

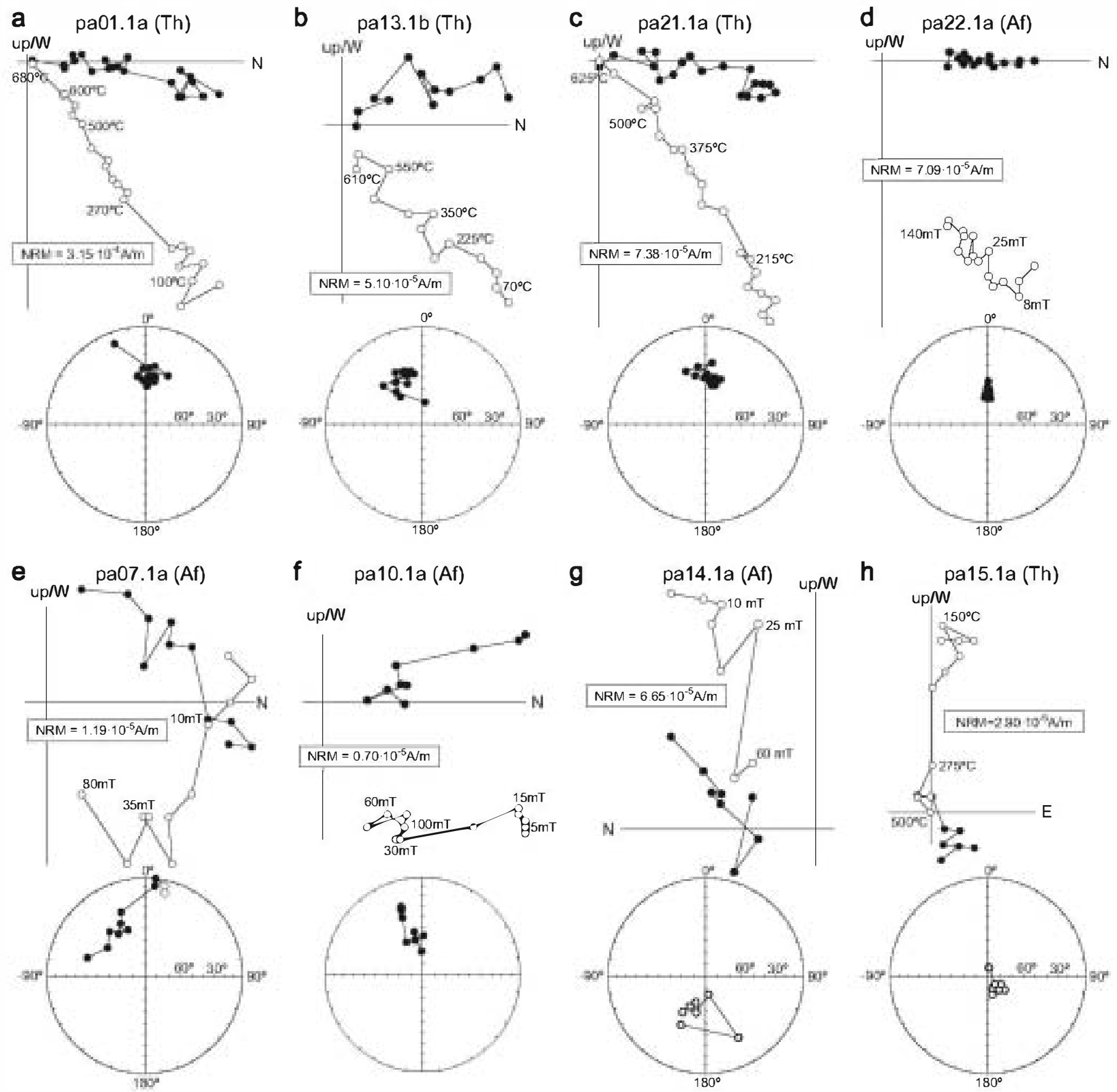

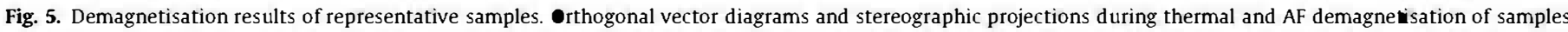

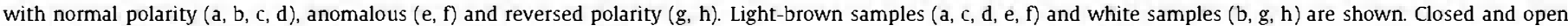
symbols: projections onto horizontal and vertical planes, respectively.

analyses performed along the growth axis of the stalagmite locate the excursion in the marine isotope substages $5 \mathrm{e} / 5 \mathrm{~d}$, in agreement with marine records of the Blake event (Lund et al., 2006; Thouveny et al., 2004). There is also weak evidence for a short angular departure (B3) of more than $45^{\circ}$ from the dipolar field between $119.3 \pm 0.8$ and $118.3 \pm 0.7 \mathrm{kyr}$ BP. No complete reversal is observed at this time.

The age (116.5-112.0 kyr BP) and total duration (4.5 kyr) of the polarity changes recorded in the speleothem seem to be consistent with data from Chinese loess obtained by Zhu et al. (1994). Their age estimations for the boundaries of the Blake event were $117.10 \pm 1.2$ up to $111.8 \pm 1.0 \mathrm{kyr}$.
The duration of the event is also consistent with the $5.5 \mathrm{kyr}$ proposal of Fang et al. (1997) obtained from Chinese palaesols. They place the beginning of the event at an age of $119.97 \mathrm{kyr}$ while we have estimated an age of $116.5 \pm 0.7 \mathrm{kyr}$. We might also consider the $\mathbf{B} 3$ anomaly, defined by a set of three samples with anomalously low inclinations (one negative) found at levels dated from $119.3 \pm 0.8$ up to $118.3 \pm 0.7$, as the beginning of the excursion. It is a short, low angle departure from the dipolar field. But, if B3 is the first event recorded in the loess palaeosols, then the last reversed episode $\mathbf{B} 1$ would be missing in that record. The estimated duration for the two reversals of Fang et al. (1997) is $1.3 \mathrm{kyr}$ (for the older) and $2.6 \mathrm{kyr}$ (for the younger), which 

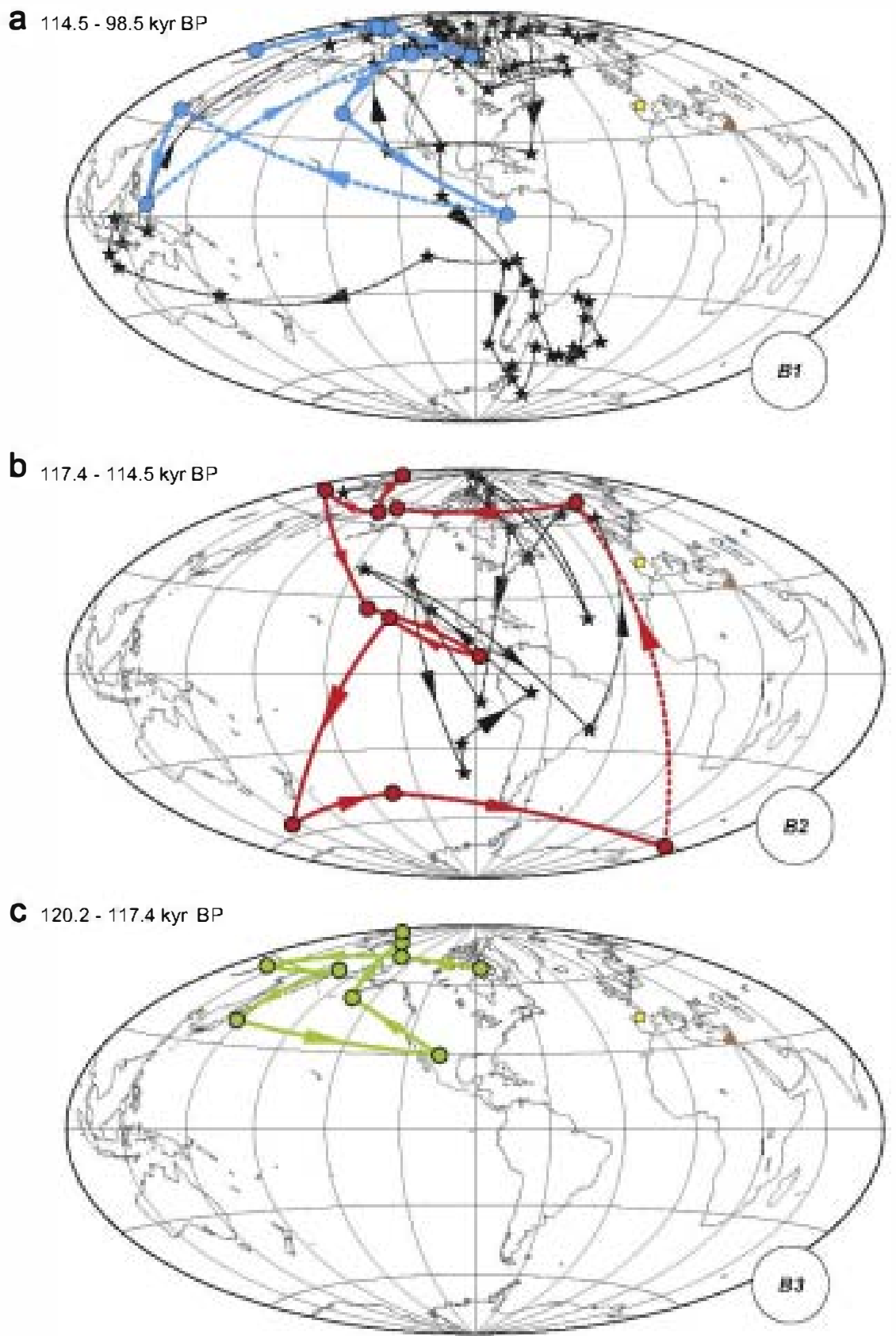

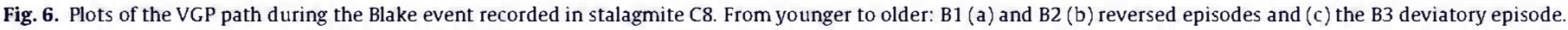

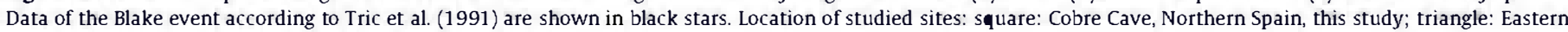
Mediterranean marine sedimentary core studied by Tric et al. (1991).

seems to be consistent with our observations of $1.6 \mathrm{kyr}$ (B2) and $2.3 \mathrm{kyr}$ (B1), respectively. The discrepancies between the loesspalaeosol record and our stalagmite record could correspond to (a) dating uncertainties associated with the loess-paleosoil profiles, or (b) a lag between the deposition time and the time when the magnetisation was acquired (e.g., Spassov et al., 2003). If magnetisation lock-in was delayed in the loess-palaeosol record, older apparent ages would be expected.

The data scarcity prevents us from defining a detailed VGP path for the transitions in stalagmite $\mathrm{C} 8$, but in order to compare our results with previous studies, the VGPs have been plotted in Fig. 6 together with the VGP transitions of the Blake event determined by Tric et al. (1991) (VGP latitude values are also plotted in Fig. $7 d$ and displayed in Supplementary Table S1). Although the differences in resolution are evident, there are some features in common: (1) the grouping of transitional poles over the East Pacific at low latitudes for the beginning of the B2 episode (Fig. 6b); (2) a southern trajectory close to the American Pacific coast for the beginning of the second event (B1) (Fig. 6a) and (3) the grouping of the poles over SE Asia that defines the end of the Blake event (Fig. 6a).

On the basis of our new U-Th age data, duration of the Blake event is $4.5 \mathrm{kyr}$, about two times longer than the Laschamp excursion. It also lasts longer than the $\sim 3 \mathrm{kyr}$ timescale predictions proposed by Gubbins (1999). The Blake event, howere is a two-fold well marked reversal in contrast to the single episode Laschamp excursion. It is intriguing that the duration of each reversed episode is within the range observed for single excursions (1.6 kyr for B2 and 2.3 kyr for B1). Laj and Channell (2007) consider that the instability associated to the Blake excursion may 


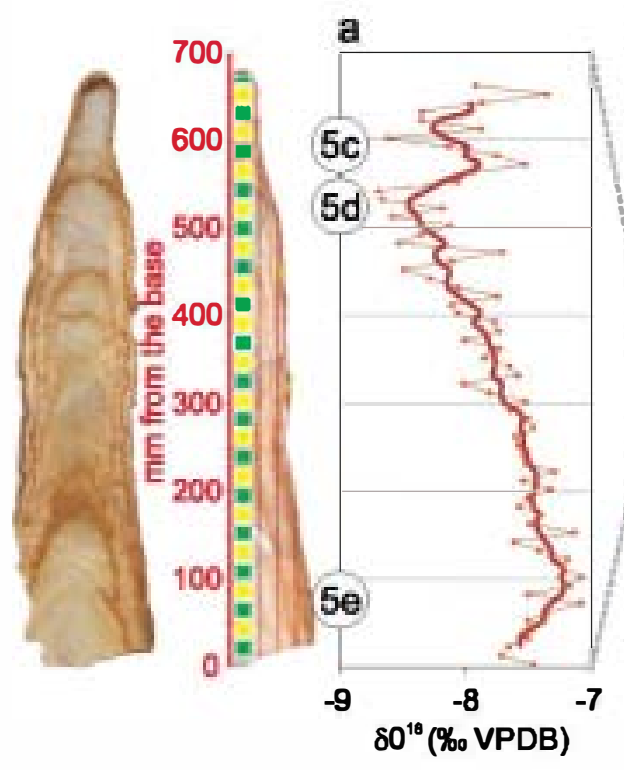

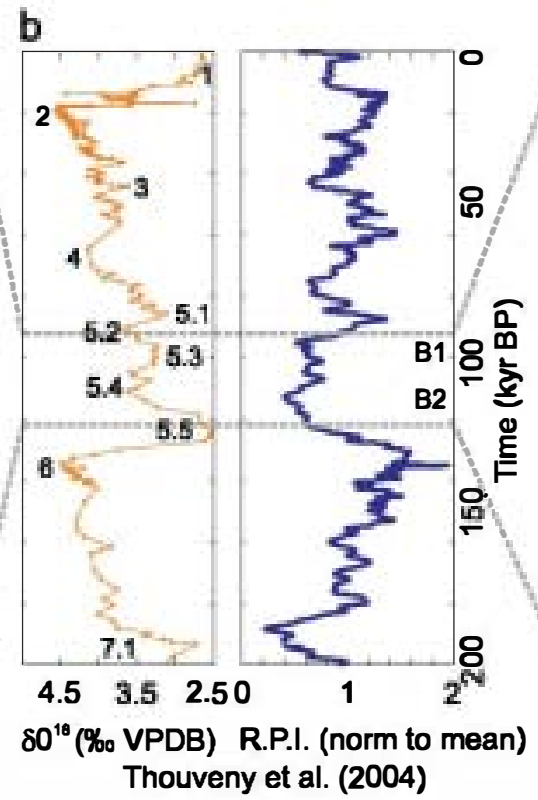

c

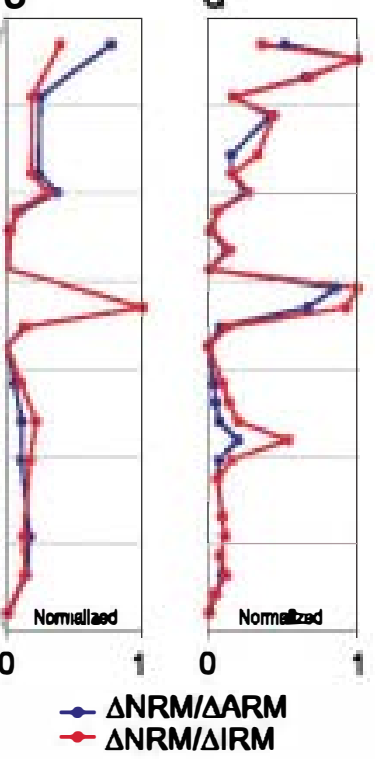

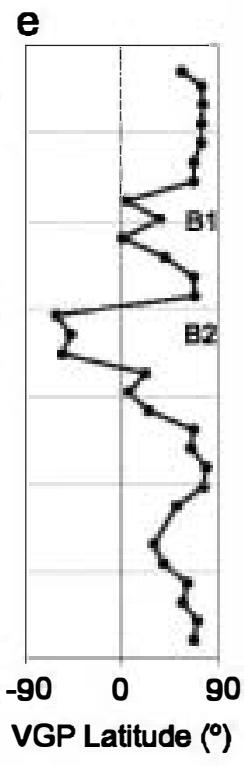

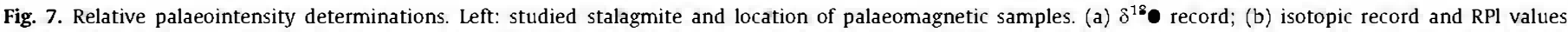

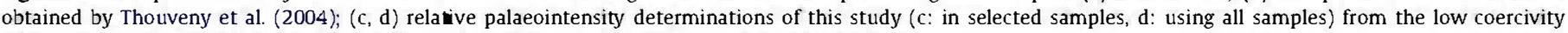
component in relation to ARM and IRM; (e) VGP latitudes. Dotted grey lines: Proposed correlation.

be explained by the observation that the critical Reynolds number for the onset of core convection is very sensitive to the poloidal field, and the strength of the core convection varies widely in response to changes in magnetic field strength particularly during intensity minima (Zhan and Gubbins, 2000). The origin of excursions remains an open question and accurate determination of their duration can be a key to constrain the geomagnetic models.

\subsection{Relative palaeointensities}

Although $\mathrm{C8}$ is not the ideal candidate to perform relative palaeointensity (RPI) studies (1) because of the presence of two magnetisation components (in some samples), and (2) because the mechanism by which NRM is acquired by speleothems is not yet well understood, we have attempted to construct a relative palaeointensity record by normalising the changes of the NRM (ChRM) by the ARM and IRM contribution of the low coercivity fraction ( $\triangle \mathrm{ARM}, \triangle \mathrm{IRM}$ ) (Fig. 7c, Supplementary Table S1). Both normalising parameters yield relative palaeointensity maxima at the time of the $\mathbf{B} 2$ reversed (the best recorded) directions and at the normally polarised top of the stalagmite. A more detailed RPI record is presented in Fig. $7 \mathrm{~d}$ using the $\triangle \mathrm{NRM}$ for all samples (i.e. including thermally demagnetised samples) relative to the $\triangle A R M$ and $\triangle I R M$ of close samples of similar lithology. The consistency of the relative RPI highs is clearly documented.

Palaeomagnetic sediment studies have well documented that the Blake excursion occurred within a broad RPI low that extended from around $125 \mathrm{kyr}$ up to $95 \mathrm{kyr}$ (Lund et al., 2006; Thouveny et al., 2004; Valet and Meynadier, 1993). According to our age model, the stalagmite C8 grew mainly within the RPI low providing another possible reason for the low NRM values observed in most of our stalagmite samples. The significance of the RPI maximum located just when the first reversal is completed is remarkable (Fig. 7c-e). Several studies have documented one or two relative maxima within the RPI low (Thouveny et al., 2004, among others), one of which could correspond to the RPI maximum obtained in our study. In addition, high resolution studies of authigenic Be isotopes from NE Atlantic sedimentary sequences indicate that the Blake event is characterised by two maxima in ${ }^{10} \mathrm{Be} /{ }^{9} \mathrm{Be}$ concentrations (geomagnetic minima) at 112 and $120 \mathrm{kyr}$ BP (Carcaillet et al., 2004). Our relative maximum is achieved at about $115.0-115.3 \mathrm{kyr}$, between the two intensity minima. Correlation with RPI records from cores from the Portuguese margin is shown in Fig. 7.

If the RPI data obtained in this study correspond to fluctuations in the intensity of the palaeofield, then the intensity of the geomagnetic field would have increased when the field completely reversed during the $\mathbf{B} 2$ event. Under this premise, at least the B2 event could be envisaged as a reversed polarity state with a dipole intensity, partly restored for a short time, which was suddenly aborted in the sense described by Valet et al. (2008).

\section{Conclusions}

A geomagnetic anomaly consisting of two periods of reversed polarity has been documented in a $68 \mathrm{~cm}$-long stalagmite from Cobre Cave, northern Spain. Its characteristic remanent magnetisation is carried by fine-grained magnetite. On the basis of U-Th dates, the anomalous event which is located in the marine substages MIS 5e/5d, occurred during the time interval of the Blake event. The speleothem event is documented by two reversed intervals (B1 and B2), with $\mathbf{B} 2$ being clearly reversely magnetised. The age of the event is estimated to be between $116.5 \pm 0.7 \mathrm{kyr} \mathbf{B P}$ and $112.0 \pm 1.9 \mathrm{kyr} \mathrm{BP}$, and has lasted for $4.5 \mathrm{kyr}$, a slightly longer duration than Laschamp, Mono Lake and Iceland Basin geomagnetic excursions (Laj and Channell, 2007). In addition to these two periods of reversed polarity a low inclination departure (B3) from the dipolar field of more than $45^{\circ}$ has also been observed in the time interval $119.3-118.3 \pm 0.7 \mathrm{kyr}$ BP.

Low values of relative palaeointensity during the Blake episode have been recognised which correlates with other sedimentary records of the Blake event. A relative maximum in the palaeofield intensity coeval with the complete reversal during the B2 interval suggests that the $\mathbf{B} 2$ interval could be envisaged as a completely reversed polarity state with a dipole contribution partly restored for a short time and then suddenly aborted.

This paper shows the potential of calcite speleothems for the study of geomagnetic excursions. Speleothems can be accurately dated, a crucial point to understand the origin of geomagnetic 
excursions. In addition, they do not show important lock-in delays of the magnetisation and present continuous deposition. Their main problems are that calcite speleothems typically have low concentrations of ferromagnetic minerals, thus, generally very weak Natural Remanent Magnetism (NRM) and poor space-resolution. With the recent development of high resolution magnetometers, rapid changes of the geomagnetic field can be reconstructed from speleothems in the near future. Here, for the first time the Blake event has been recognised in a stalagmite from northern Spain for which accurate absolute dating has been carried out using the uranium-series disequilibrium technique.

\section{Acknowledgements}

We greatly thank the permissions given by the Junta de Castilla y León (Spain) for accessing and working in the Fuentes Carrionas-Fuente Cobre Natural Park The work was carried out with the support of the following Projects/Grants: PR-2007-0111, CGL2007-60618-BTE, CGL2008-02203/BTE, CGL2010-21499-BTE and CGI.2011-24790. This paper is a contribution to UCM research groups 910396 "Paleomagnetism" and 910198 "Palaeoclimatology and Global Change". We thankJ.M. Feinberg for the review of a preliminary manuscript.

\section{Appendix A. Supporting information}

Supplementary data associated with this article can be found in the online version at http://dxdoi.org/10.1016/j.epsl.2012.07.041.

\section{References}

Bleil, U., Gard, G., 1989. Chronology and correlation of Quaternary magnetostratigraphy and nannofossil biostratigraphy in Norwegian-Greenland Sea sediments. Geol. Rundsch 78, 1173-1187.

Carcaillet, J., Bourles, D.L., Thouveny, N., Arnold, M., 2004. An authigenic 10-Be/9-Be record of geomagnetic moment variations and excursions over the last $300 \mathrm{ka}$ Earth Planet. Sci. Lett. 219, 397-412.

Channell, J.E.T., 2006. Late Brunhes polarity excursions (Mono Lake, Laschamp, Iceland Basin and Pringle Falls) recorded at ODP site 919 (Irminger Basin) Earth Planet. Sci. Lett. 244, 378-393.

Cheng, H., Edwards, R.L, Hoff, J., Gallup, C.D., Richards, D.A., Asmerom, Y., 2000 The half-lives of uranium-234 and thorium-230. Chem Geol. 169,17-33.

Creer, K.M., Readman, P.W., Jacobs, A.M., 1980. Palaeomagnetic and palaeontological dating of a section at Gioia Tauro, Italy: identification of the Blake event Earth Planet. Sci. Lett. 50, 289-300

Denham, C.R, 1976. Blake polarity episode in two cores from the Greater Antilles outer ridge. Earth Planet. Sci. Lett. 29, 422-434.

Dorale, J.A., Edwards, RL., Alexander, E.C., Shen, C.-C., Richards, D.A., Cheng, $\mathrm{H}$, 2004. U-series dating of speleothems: techniques, limits, and applications. In Sasowsky, 1.D., Mylroic, J.E. (Eds.), Studies of Cave Sediments. Kluwer Aca demic/Plenum Publishers, New York, pp. 177-197.

Edwards, RL, Chen, J.H., Wasserburg, G.J., 1987. ${ }^{238} \mathrm{U}-{ }^{234} \mathrm{U}-{ }^{230} \mathrm{Th}-{ }^{232} \mathrm{Th}$ systematics and the precise measurement of time over the past 500,000 years. Earth Planet Sci. Lett. 81, 175-192.

Egli, R, Lowrie, W., 2003. Anhysteretic remanent magnetisation of fine magnetic particles. J. Geophys. Res. 107 (B10), 2209.

Egli, R, 2004. Characterization of individual rock magnetic components by analysis of remanence curves, unmixing natural sediments. Stud. Geophys. Geod. 48 (2), 391-446

Fang, X.M., Li, J.J., Van der Voo, R, Mac Niocaill, C., Dai, X.R, Kemp, R.A., Derbyshire, E., Cao, J.X., Wang, J.M., Wang, G., 1997. A record of the Blake event during the last interglacial paleosol in the western Loess Plateau of China. Earth Planet. Sci. Lett $146,73-82$

Frisia, S., Borsato, A., Fairchild, I.J., McDermott, F., 2000. Calcite fabrics, growth mechanisms, and environments of formation in speleothems from the Italian Alps and Southwestern Ireland. J. Sediment. Res. 70, 1183-1196.

Gubbins, D., 1999. The distintion between geomagnetic excursions and reversals. Geophys. J. Int. 137, F1-F3.
Laj, C., Channell, J.E.T., 2007. Geomagnetic excursions. In: Geomagnetism: Treatise on Geophysics, vol. 5. Elsevier, pp. 373-416

Langereis, C.G., Dekkers, M.J., de Lange, G.J., Paterne, M., van Santvoort, P.J.M., 1997. Magnetostratigraphy and astronomical calibration of the last $1.1 \mathrm{Myr}$ from an eastern Mediterranean piston core and dating of short events in the Brunhes. Geophys. J. Int 129, 75-94.

Lascu, I., Feinberg, J.M., 2011. Speleothem magnetism. Quat Sci. Rev. 30 , 3306-3320

Latham, A.G., Schwarcz, H.P., Ford, D.C., Pearce, G.W., 1979a. Palaeomagnetism of stalagmite deposits. Nature 280, 383-385.

Latham, A.G., Schwarcz, H.P., Ford, D.C., Pearce, G.W., 1979b. The paleomagnetism and $U$-Th dating of three Canadian speleothems: evidence for westward drift, 5.4-2.1 ka BP. Can. J. Earth Sci. 19, 1985-1995.

Latham, A.G., Schwarcz, H.P., Ford, D.C., 1987. Secular variation of the Earth's magnetic field from 18.5 to $15.0 \mathrm{ka} \mathrm{BP}$, as recorded in a Vancouver Island stalagmite. Can. J. Earth Sci. 24, 1235-1241.

Lowrie, $\mathbf{W}$., 1990. Identification of ferromagnetic minerals in a rock by coercivity and unblocking temperature properties. Geophys. Res. Lett. 17, 159-162.

Lund, S., Stoner, J.S., Channell, J.E.T., Acton, G., 2006. A summary of Brunhes palaeomagenetic field variability recorded in Ocean Drilling Programs cores. Phys. Earth Planet. Inter. 156, 194-204.

Muñoz-García, M.B., 2007. Estudio de los espeleotemas recientes de Cueva del Cobre (Palencia) como indicadores de variabilidad paleoclimática. Ph.D. Thesis. Universidad Complutense de Madrid, 307 pp.

Muñoz-García, M.B., Marín-Chivelet, J., Rossi, C., Ford, D.C., Schwarcz, H.P., 2007. Chronology of Termination II and the Eemian period in Southern Europe based on $\mathrm{U}$-Th dating and stable isotope chronology of stalagmites from Cueva del Cobre (N Spain). J. Iberian Geol. 33 (1), 17-30

-penshaw, S., Latham, A., Shaw, J., Zhu, X.W., 1993. Preliminary results on recent palaeomagnetic secular variation recorded in speleothems from Xingwen, Sichuan, China. Cave Sci. 20 (3), 93-99.

Perkins, A.M., Maher, B.A., 1993. Rock magnetic and palaeomagnetic studies of British speleothems. J. Geomagn. Geoelectr. 45, 143-153.

Perkins, A.M., 1996. bservations under electron microscopy of magnetic minerals extracted from speleothems. Earth Planet. Sci. Lett. 139, 281-289.

Reinders, J., Hambach, U., 1995. A geomagnetic event recorded in loess deposits of the Tönchesberg (Germany): identification of the Blake magnetic polarity episode. Geophys. J. Int. 122, 407-418.

Roberts, A., 2008. Geomagnetic excursions: knowns and unknowns. Geophys. Res. Lett 35, L17307, http://dx.doi.org/10.1029/2008GL034719.

Rossi, C. Muñoz, A., Cortel, A., 1997. Cave development along the water table in Cobre System (Sierra de Peñalabra, Cantabrian Mountains, N Spain). In: Proceedings of the 12th International Congress of Speleology, Switzerland, pp. 179-182.

Scholz, D., Hoffmann, D., 2011. An algorithm designed for construction of speleothem age models. Quat Geochronol. 6, 369-382.

Shen, C.C., Edwards, RL. Cheng, H., Dorale, J.A., Thomas, R.B., Moran, S.B. Weinstein, S., Hirschmann, M., 2002. Uranium and thorium isotopic and concentration measurements by magnetic sector inductively coupled plasma mass spectrometry. Chem. Geol. 185, 165-178.

Shier, M.J., Roebroeks, W., Bakels, C.C., Dekkers, M.J., Brühl, E., De Loecker, D. Gaudzinski-Windheuser, S., Hesse, N., Jagich, A., Kindler, L., Kuijper, W.J. Laurat, T., Mücher, H.J., Penkman, E.H., Ritcher, D., van Hinsbergen, D.J.J, 2011. Direct terrestial-marine correlation demonstrates surprisingly late onset of the last interglacial in central Europe 75, 213-218Quat. Res. 75, 213-218.

Smith, J.D., Foster, J.H., 1969. Geomagnetic reversal in the Brunhes normal polarity epoch. Science 163, 565-567.

Spassov, S., Heller, F., Evans, M.E., Yue, L.P., Dobeneck, T.v., 2003. A lock-in model for the complex Matuyama-Brunhes boundary record of the loess/paleosol sequence at Lingtai (Central Chinese Loess Plateau). Geophys. J. Int. 155, 350-366.

Tauxe, L, 1993. Sedimentary records of relative paleointensity of the geomagnetic field: theory and practice. Rev. Geophys. 31, 319-354.

Thouveny, N., Carcaillet, J., Moreno, E., Leduc, G., Nérini, D., 2004. Geomagnetic moment variation and palaeomagnetic excursions during the last $400 \mathrm{ka}$ : stacked record from sedimentary cores of the Portuguese margin. Earth Planet. Sci. Lett. 219, 377-396.

Tric, E., Laj, C., Valet, J.P., Tucholka, P., Guichard, F., 1991. The Blake geomagnetic event: transition geometry, dynamical characteristics and geomagnetic significance. Earth Planet. Sci. Lett. 102, 1-13.

Tucholka, P., Fontugne, M., Guichard, F., Paterne, M., 1987. The Blake magnetic polarity episode in cores from the Mediterranean. Earth Planet. Sci. Lett. 86, 320-326.

Valet, J.P., Meynadier, L, 1993. Geomagnetic field intensity and reversals during the last four million years. Nature $366,235-238$.

Valet, J.P., Plenier, G., Herrero-Bervera, E., 2008. Geomagnetic excursions reflect an aborted polarity state. Earth Planet. Sci. Lett. 274, 472-478.

Zhan, K, Gubbins, D., 2000. Is the geodynamo intrinsically unestable? Geophys. J. Int. 140, F1-F4

Zhu, RX., Zhou, L.P., Laj, C., Mazaud, A., Ding, Z.L, 1994. The Blake geomagnetic polarity episode recorded in Chinese loess. Geophys. Res. Lett. 21, 697-700 